デッカ航法利用による船舶の運動性能、

ロラン位置の精度、海流の測定について

\title{
On the Measurement and Qbservation of the ship's Maneuverability, the Accuracy of Positions by Loran and the Oceanic Current, using Decca Fixing.
}

\author{
沓 名 景 義 (水路部) \\ 重広敏(")
}

\begin{abstract}
The position fixed by Decca has correspondingly the same degree of accuracy with that of the triangular survey using landmarks.

From this point of view, the following studies in which Decca was utilized were carried out during the hydrographic surveying conducted August through September, 1959, off Tokati, Hokkaido, by the Japanese Hydrographic Office:

1) Measurement of the Survey Ship Takuyo's maneuverability (turning circle and distance of new course).

2) Observation of currents using ship's positions by Decca and dead reckoning, comparing the results with those obtained by G.E. K.

3) Measurement of the accuracy of positions by Loran.

As to the result of 1), a considerable accuracy was ascertained in the ship's turning circle obtained.

The result of 2) revealed that the values obtained by means of Decca and dead reckoning were approximately the same as those of G.E.K.

As to the result of 3), ship's positions by Loran rate $2 \mathrm{~S} 1$ were obtained within 1 mile error, but when using the rate $2 \mathrm{~S} 2$, positions could not be obtained so accurately, in some cases with errors ranging from 5 to 7 miles, because of being in the proximity of the base line extension.

水路部では今年 8 月中旬から 9 月下旬にかけて北海道十勝沖の海洋測量をデッカを利用して行 つた。デッカの精度は条件の良い処では $5 \mathrm{~m}$ オーダーの精度があるので、デッカ位置の精度の良 いのを利用して次ぎのような実験を行つたので、それらについて述べる。
\end{abstract}

\section{1. 実 験 項 目}

（1）測量船拓洋の運動性能

（2）ロラン測定船位の精度 
(3) GE Kによる海流調査

（4）推測位置と実測位置（デッカ測定位置）との差からの海流調査

(5) GEKとの比較

\section{2. デッカについて}

デッカはロランと同じように双曲線航法用のものであるが、ロランが両局からの電波の到着時 間差によつて船位を求めるのに対し、デッカは位相差を測定して船位を求めるものである。

デッカの要目はつぎのとおりである。

(保局位置

主局 白糠、従局の R局 広尾、G局 霧多布、監視局 制路

(口) 局間距離 $\mathrm{R} \quad 50 \mathrm{M} 、 \mathrm{G} \quad 49 \mathrm{M}$

（认）周波数 主局71.04kc、従局のR局 $94.72 \mathrm{kc} 、 \mathrm{G}$ 局 $106.56 \mathrm{kc}$

$\Leftrightarrow$ 比較周波数 R284.16kc、G213.12kc

(林) 基線上 1 レーンの長さ R527.17m、G702.89m

( 1ゾーンにおけるレーン数 R24レーン、G20レーン

(ト) 測量範囲 局から最大 $130 \mathrm{M}$

デッカ精度については陸上原点の視認できる处で、三角測量により求めた船位とデッカ船 位とのチェックをし、その地点から沖合に向かいデッカ測量を実施し、反転して陸岸に近づ く度に三角測量をしてチェックしたが許容誤差内であつたので、一応デッカ位置は正しいも のと仮定して害験を行つた。

デッカ精度についてはデッカ会社発行の F.1 を参照のてと。

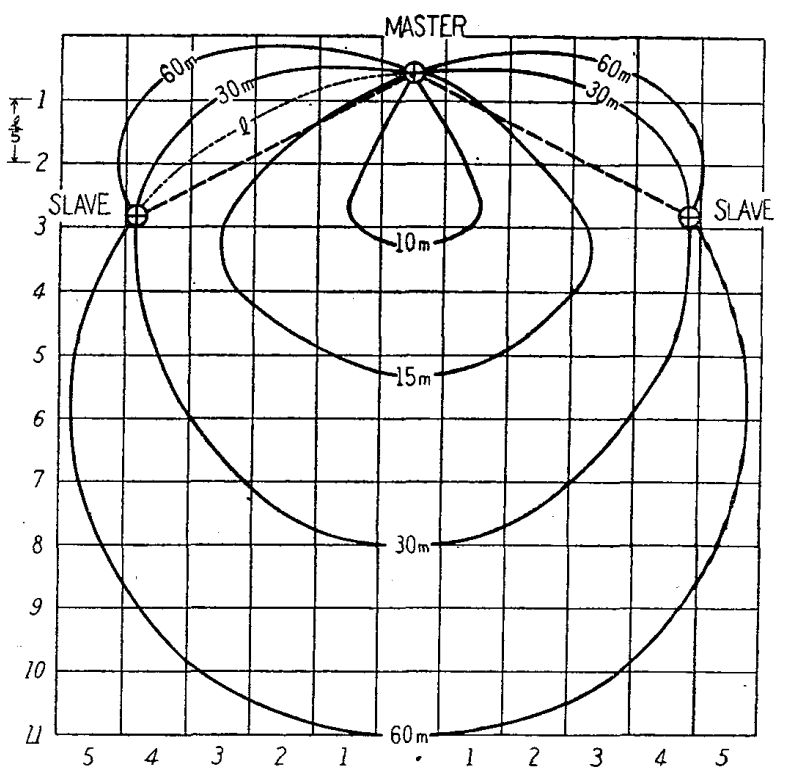

Fig. 1 ACCURACY CONTOURS

FOR A STANDARD DEVIATION OF.OI MEAN LANE

\section{3. 拓洋の運動性能}

(1) 拓洋の要目

総屯数 $770.29 \mathrm{~T}$ 純屯数 $197.97 \mathrm{~T}$

排水灾 $853.00 \mathrm{~T}$ 全長 $62.40 \mathrm{~m}$ 
垂線間恠 $57.72 \mathrm{~m}$ 幅 $9.48 \mathrm{~m}$ 樑さ $4.79 \mathrm{~m}$

吃水 F。 $2.89 \mathrm{~m}$ A $3.06 \mathrm{~m}$ 速力 最大 $14 \mathrm{Kt}$ 通常 $12.5 \mathrm{k}$ 亿

(2) 旋回圈の測定（別表第1、節2、F。3参照）

デッカ精度の比較的良い地点を撰んで実施した。

観測方法は 5 秒間隔にデコメーター（R及び $\mathrm{G} ）$ の示度、船首方位、傾斜、回転数、速力 を記録し、方眼紙上に $\frac{1}{1000}$ の縮尺で図化した。各測点の誤差は最大 $13 \mathrm{~m} \sim 15 \mathrm{~m}$ で比較的正 しい圈を求めるてとができた。

(イ）デコメーターの示度を実長に換算する方法

測定地点の $\mathrm{R} 及 ひ ゙ \mathrm{G} の 1$ レーンの長さを $\frac{1}{5 \text { 万 }}$ のデッカ曲線から求め、それれデコメーターの 示度を乗して実長を求める。

すなわち、1レーンの長さは

$$
\begin{aligned}
& \text { R } \quad 15.5 \mathrm{~mm} \times 50,000=775 \mathrm{~m} \\
& G \quad 17.3 \mathrm{~mm} \times 50,000=865 \mathrm{~m}
\end{aligned}
$$

で実際の長さは

$$
\begin{array}{ll}
R & 775 \mathrm{~m} \times R \text { の示度 } \\
G & 865 \mathrm{~m} \times G \text { の示度 }
\end{array}
$$

となる。

この附近ではデッカ、パタンは直交していないので直角座標に転換する（F.2参照）

斜軸座標を $x 、 y$ 、直角座標を $X 、 Y$ 、交角を $90^{\circ}+\theta^{\circ}$ とすれば

$$
\begin{aligned}
X & =x-y \sin \theta \\
Y & =y \cos \theta \\
\theta & =2.5^{\circ} \sim 6^{\circ} \text { で微小故 } \\
X & =y-\frac{y \cdot \theta}{60} \\
Y & =y
\end{aligned}
$$

\begin{tabular}{|c|c|c|c|c|c|c|c|c|c|c|c|c|}
\hline \multirow{2}{*}{ 回数 } & \multirow{2}{*}{ 時 間 } & \multicolumn{2}{|c|}{ デコメーターの示度 } & \multicolumn{2}{|c|}{ 奏 際 の 長 さ } & \multirow{2}{*}{ 船首方向 } & \multirow{2}{*}{ 傾斜 } & \multicolumn{2}{|c|}{ 回 転 数 } & \multirow{2}{*}{ 速力 } & \multirow{2}{*}{ 記 } & \multirow{2}{*}{ 牙 } \\
\hline & & $\mathrm{R}$ & G & $\mathrm{R}$ & $\mathrm{G}$ & & & 左 & 右 & & & \\
\hline $\begin{array}{l}1 \\
2 \\
3 \\
4 \\
5\end{array}$ & $\begin{array}{r}\mathrm{m} \text { s } \\
0-00 \\
5 \\
10 \\
15 \\
20\end{array}$ & \begin{tabular}{|r|} 
A $20-66.0$ \\
71.3 \\
74.0 \\
77.0 \\
80.1
\end{tabular} & $\begin{array}{r}\text { B } 34-15.3 \\
14.2 \\
12.5 \\
11.7 \\
09.8\end{array}$ & $\begin{array}{r}m \\
513.8 \\
552.6 \\
573.5 \\
596.8 \\
620.8\end{array}$ & $\begin{array}{r}\mathrm{m} \\
943.3 \\
929.7 \\
912.8 \\
904.5 \\
884.6\end{array}$ & $\begin{array}{l}210^{\circ} \\
211 \\
215 \\
221 \\
230\end{array}$ & 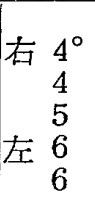 & $\begin{array}{c}275 \\
280 \\
11 \\
285 \\
" 1\end{array}$ & $\begin{array}{l}275 \\
270 \\
\text { " } \\
260 \\
250\end{array}$ & $\begin{array}{l}\mathrm{kt} . \\
13.0 \\
12.9 \\
12.7 \\
12.3 \\
12.1\end{array}$ & & \\
\hline $\begin{array}{r}6 \\
7 \\
8 \\
9 \\
10\end{array}$ & $\begin{array}{l}25 \\
30 \\
35 \\
40 \\
45\end{array}$ & $\begin{array}{l}81.7 \\
83.8 \\
86.0 \\
86.0 \\
86.8\end{array}$ & $\begin{array}{r}07.8 \\
05.0 \\
02.6 \\
00.0 \\
33-97.5\end{array}$ & $\begin{array}{l}633.2 \\
649.4 \\
666.5 \\
666.5 \\
672.7\end{array}$ & $\begin{array}{l}866.0 \\
840.2 \\
817.5 \\
795.0 \\
772.7\end{array}$ & $\begin{array}{l}240 \\
253 \\
265 \\
277 \\
291\end{array}$ & $\begin{array}{l}0 \\
3 \\
6 \\
3 \\
3\end{array}$ & $\begin{array}{c}\prime \prime \\
270 \\
\prime \prime \\
260\end{array}$ & $\begin{array}{c}\prime \prime \\
225 \\
230 \\
11 \\
220\end{array}$ & $\begin{array}{r}11.8 \\
10.7 \\
10.6 \\
10.2 \\
9.8\end{array}$ & & ' \\
\hline
\end{tabular}

となる。

この附近では真北は $Y$ 軸に対し左へ $6^{\circ} \sim 8^{\circ}$ 偏 している。

(口) 別表第 1 は原速で面舵 $15^{\circ}$ のときの旋氤圈 別表第 1. 旋回图 原速 面舵 $15^{\circ}$

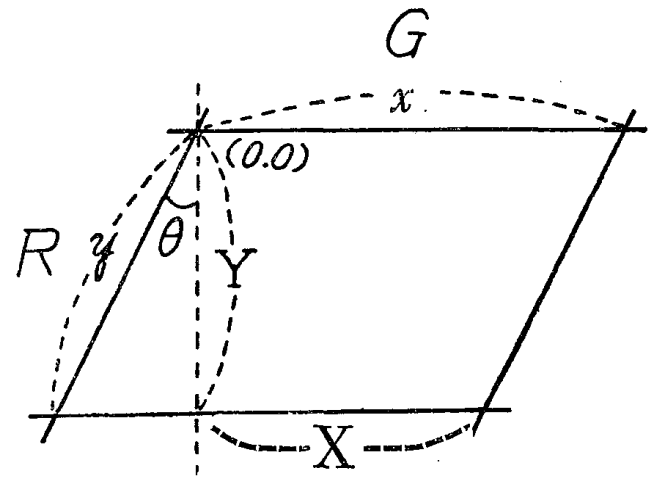

Fig. 2

風向 $\mathrm{N}$ 風速 $2 \sim 5 \mathrm{~m} / \mathrm{s}$ ウネリ $\mathrm{E} 1$ 


\begin{tabular}{|c|c|c|c|c|c|c|c|c|c|c|c|}
\hline \multirow{2}{*}{ 回数 } & \multirow{2}{*}{ 時 間 } & \multicolumn{2}{|c|}{ デコメーターの示度 } & \multicolumn{2}{|c|}{ 実 際 の 長ささ } & \multirow{2}{*}{ 船筸打间 } & \multirow{2}{*}{ 傾涂 } & \multicolumn{2}{|c|}{ 回 転 数 } & \multirow{2}{*}{ 萪力 } & \multirow{2}{*}{ 記 躬 } \\
\hline & & $\mathrm{R}$ & $\mathrm{G}$ & $\mathrm{R}$ & $\mathrm{G}$ & & & 左 & 在 & & \\
\hline $\begin{array}{l}11 \\
12 \\
13 \\
14 \\
15\end{array}$ & $\begin{array}{r}50 \\
55 \\
1 \sim 00 \\
10 \\
20\end{array}$ & $\begin{array}{l}85.9 \\
84.8 \\
82.5 \\
77.8 \\
73.7\end{array}$ & $\begin{array}{l}94.7 \\
91.8 \\
89.6 \\
85.9 \\
84.3\end{array}$ & $\begin{array}{l}665.7 \\
657.2 \\
639.4 \\
602.9 \\
571.2\end{array}$ & $\begin{array}{l}749.3 \\
725.1 \\
707.9 \\
679.7 \\
669.2\end{array}$ & $\begin{array}{r}303 \\
314 \\
326 \\
349 \\
12\end{array}$ & $\begin{array}{l}3 \\
3 \\
2 \\
2 \\
3\end{array}$ & $\begin{array}{c}260 \\
\prime \prime \\
250 \\
\prime \prime \\
\prime \prime\end{array}$ & $\begin{array}{c}225 \\
220 \\
\prime \prime \\
215 \\
\prime \prime\end{array}$ & $\begin{array}{r}10.0 \\
9.5 \\
9.0 \\
\prime \prime \\
8.5\end{array}$ & $\begin{array}{l}90^{\circ} \text { 回頭 } \\
0 \mathrm{~m} \sim 51 \mathrm{~s}\end{array}$ \\
\hline $\begin{array}{l}16 \\
17 \\
18 \\
19 \\
20\end{array}$ & $\begin{array}{r}30 \\
40 \\
50 \\
2 \sim 00 \\
10\end{array}$ & $\begin{array}{l}67.7 \\
61.5 \\
58.7 \\
56.5 \\
57.3 \\
\end{array}$ & $\begin{array}{r}84.5 \\
86.2 \\
90.5 \\
95.7 \\
34 \sim 00.3\end{array}$ & $\begin{array}{l}524.7 \\
476.6 \\
454.9 \\
437.9 \\
444.1\end{array}$ & $\begin{array}{l}675.8 \\
695.5 \\
734.2 \\
776.7 \\
821.0\end{array}$ & $\begin{array}{r}33 \\
55 \\
75 \\
98 \\
118\end{array}$ & $\begin{array}{l}0 \\
6 \\
5 \\
1 \\
0\end{array}$ & $\begin{array}{c}\prime \prime \\
245 \\
\prime \prime \\
250 \\
245\end{array}$ & $\begin{array}{l}\prime \prime \\
" 1 \\
210 \\
215 \\
210\end{array}$ & $\begin{array}{l}\prime \prime \\
11 \\
8.6 \\
8.5 \\
8.3\end{array}$ & $\begin{array}{l}180^{\circ} \text { 回頭 } \\
1 \mathrm{~m} \sim 21 \mathrm{~s}\end{array}$ \\
\hline $\begin{array}{l}21 \\
22 \\
23 \\
24 \\
25\end{array}$ & $\begin{array}{r}20 \\
30 \\
40 \\
50 \\
3 \sim 00\end{array}$ & $\begin{array}{l}60.1 \\
64.2 \\
69.4 \\
74.2 \\
78.8\end{array}$ & $\begin{array}{r}05.2 \\
09.5 \\
12.0 \\
13.2 \\
12.2\end{array}$ & $\begin{array}{l}465.8 \\
497.5 \\
530.1 \\
567.3 \\
602.9\end{array}$ & $\begin{array}{l}861.1 \\
894.9 \\
913.1 \\
919.7 \\
907.2\end{array}$ & $\begin{array}{l}140 \\
160 \\
181 \\
202 \\
223\end{array}$ & $\begin{array}{l}2 \\
5 \\
1 \\
3 \\
3\end{array}$ & $\begin{array}{l}1 \\
" 1 \\
" 1 \\
" 1\end{array}$ & $\begin{array}{c}215 \\
\prime \prime \\
210 \\
\prime \prime \\
215\end{array}$ & $\begin{array}{l}8.5 \\
8.6 \\
8.1 \\
8.3 \\
8.6\end{array}$ & $\begin{array}{l}270^{\circ} \text { 回頭 } \\
2 \mathrm{~m} \sim 12 \mathrm{~s}\end{array}$ \\
\hline $\begin{array}{l}26 \\
27 \\
28 \\
29 \\
30\end{array}$ & $\begin{array}{r}0 \\
20 \\
30 \\
40 \\
50\end{array}$ & $\begin{array}{l}82.1 \\
85.0 \\
85.3 \\
83.7 \\
80.1\end{array}$ & $\begin{array}{r}09.0 \\
04.8 \\
00.8 \\
33 \sim 96.2 \\
92.2\end{array}$ & $\begin{array}{l}628.5 \\
651.0 \\
653.3 \\
640.9 \\
613.0\end{array}$ & $\begin{array}{l}876.9 \\
838.1 \\
803.3 \\
764.8 \\
733.1\end{array}$ & $\begin{array}{l}245 \\
266 \\
286 \\
307 \\
327\end{array}$ & $\begin{array}{l}2 \\
2 \\
2 \\
3 \\
2\end{array}$ & $\begin{array}{c}11 \\
11 \\
11 \\
240 \\
\prime \prime\end{array}$ & $\begin{array}{c}11 \\
11 \\
11 \\
11 \\
210\end{array}$ & $\begin{array}{l}11 \\
1 " \\
8.3 \\
11 \\
8.0\end{array}$ & $3 \mathrm{~m} \sim 00 \mathrm{~s}$ \\
\hline $\begin{array}{l}31 \\
32 \\
33 \\
34 \\
35\end{array}$ & $\begin{array}{r}\sim 00 \\
10 \\
20 \\
30 \\
40\end{array}$ & $\begin{array}{l}76.8 \\
72.3 \\
65.0 \\
60.9 \\
56.8\end{array}$ & \begin{tabular}{l|}
88.8 \\
82.5 \\
87.5 \\
89.3 \\
93.5
\end{tabular} & $\begin{array}{l}587.4 \\
552.6 \\
496.0 \\
464.2 \\
432.4\end{array}$ & $\begin{array}{l}706.5 \\
655.5 \\
704.8 \\
733.7 \\
763.4\end{array}$ & $\begin{array}{r}348 \\
10 \\
31 \\
51 \\
72\end{array}$ & $\begin{array}{l}3 \\
2 \\
5 \\
1 \\
1\end{array}$ & $\begin{array}{c}245 \\
" 1 \\
\prime \prime \\
\prime \prime \\
1 "\end{array}$ & $\begin{array}{c}215 \\
" 1 \\
" 1 \\
" 1 \\
\prime \prime\end{array}$ & $\begin{array}{l}8.3 \\
8.5 \\
11 \\
8.3 \\
8.3\end{array}$ & \\
\hline & & & & L & 下 & 略 & & & & & \\
\hline
\end{tabular}

drift angle $8 \sim 10^{\circ}$

註＼cjkstart講演会席上で配布したプリント币「デコメーターの示度」及び「垁際の長さ」の「G」の数值が 間違つていましたので、おわびして訂正します。

别表第 2. 旋回圈

\begin{tabular}{|c|c|c|c|c|c|c|c|c|}
\hline 月 日 天候 & \multirow{2}{*}{\multicolumn{2}{|c|}{8 月 21 日 }} & \multicolumn{2}{|l|}{ Calm } & \multicolumn{2}{|c|}{$\begin{array}{l}\text { 海流 } 265^{\circ} \\
(\mathrm{G} . \mathrm{E} . \mathrm{K}) 0.5 \mathrm{kt}\end{array}$} & \multicolumn{2}{|c|}{$\begin{array}{l}\text { 風向 } \mathrm{N} \text { 海流 } 60^{\circ} 0.5 \mathrm{kt} \\
\text { 風速 } 5 \mathrm{~m} / \mathrm{s} \\
\mathrm{G} . \mathrm{E} . \mathrm{K} .350^{\circ} 0.1 \mathrm{kt}\end{array}$} \\
\hline 力 & & & & 速 & 半 & 速 & 原 & 速 \\
\hline 舵 & 舵 目 & 15 。 & 舵 目 & $35^{\circ}$ & 舵 & $35^{\circ}$ & 舵 角 $15^{\circ}$ & 角 35 。 \\
\hline 面舵 取舵別 & 面 舵 & 取 舵 & 面 舵 & 取 舵 & 面 舵 & 取 舵 & 面 舵 & 舵 \\
\hline 最初の針路 & $200^{\circ}$ & $200^{\circ}$ & $70^{\circ}$ & $30^{\circ}$ & $310^{\circ}$ & $180^{\circ}$ & $210^{\circ}$ & $210^{\circ}$ \\
\hline $\begin{array}{l}\text { Advance } \\
\text { DA (Max) }\end{array}$ & $213 \mathrm{~m}$ & $248 \mathrm{~m}$ & $\begin{array}{c}153 \mathrm{~m} \\
(145)\end{array}$ & $143 m$ & $169 \mathrm{~m}$ & $153 \mathrm{~m}$ & $212 \mathrm{~m}$ & $\begin{array}{l}181 \mathrm{~m} \\
(178)\end{array}$ \\
\hline $\begin{array}{l}\text { Transfer } \\
\text { DT (Max) }\end{array}$ & $\begin{array}{c}235 \\
(255)\end{array}$ & $\begin{array}{c}269 \\
(255)\end{array}$ & 142 & $\begin{array}{c}139 \\
(148)\end{array}$ & $\begin{array}{c}142 \\
(128)\end{array}$ & $\begin{array}{c}153 \\
(137)\end{array}$ & $\begin{array}{c}240 \\
(236) \\
\end{array}$ & 150 \\
\hline$\frac{\mathrm{DA}}{\mathrm{L}}$ & 3.42 & 3.97 & 2.45 & 2.29 & 2.70 & 2.45 & 3. 40 & 2.90 \\
\hline$\frac{\mathrm{DT}}{\mathrm{L}}$ & 3.77 & 4. 30 & 2.28 & 2.23 & 2.28 & 2.45 & 3.85 & 2. 40 \\
\hline 最大傾 斜 & 左 4 & 右 5 & 左 5 & 右 5 & 左 4 & 杏 3 & 左 6 & 右 8 \\
\hline 00。回 時 間 & $0 \mathrm{~m} \sim 50 \mathrm{~s}$ & $\mathrm{~m} \sim 57 \mathrm{~s}$ & $m \sim 37 \mathrm{~s}$ & $0 \mathrm{~m} \sim 35 \mathrm{~s}$ & $0 \mathrm{~m} \sim 50 \mathrm{~s}$ & $0 \mathrm{~m} \sim 50 \mathrm{~s}$ & $0 \mathrm{~m} \sim 51 \mathrm{~s}$ & $0 \mathrm{~m} \sim 44 \mathrm{~s}$ \\
\hline 速 力 & & & & $8.0 \mathrm{kt}$ & $5.0 \mathrm{kt}$ & $5.1 \mathrm{kt}$ & $10.0 \mathrm{kt}$ & $6.7 \mathrm{kt}$ \\
\hline 時 間 & $1 \sim 20$ & $1 \sim 37$ & $1 \sim 12$ & $1 \sim 10$ & $1 \sim 42$ & $1 \sim 40$ & $1 \sim 21$ & $1 \sim 10$ \\
\hline 速 力 & & & & 5.2 & 3.3 & 3.5 & 8.5 & 5.3 \\
\hline $270^{\circ}$ 回 & $2 \sim 04$ & $2 \sim 12$ & $1 \sim 55$ & $1 \sim 50$ & $2 \sim 37$ & $2 \sim 31$ & $2 \sim 12$ & $1 \sim 50$ \\
\hline 260 頭 & & & & 5.2 & 3.3 & 3.4 & 8.4 & 5.5 \\
\hline $360^{\circ}$ 。回 & $2 \sim 50$ & $2 \sim 57$ & $2 \sim 20$ & $2 \sim 17$ & $3 \sim 30$ & $2 \sim 25$ & $3 \sim 00$ & $2 \sim 22$ \\
\hline 頭速 力 & & & & 5.2 & 3.3 & 3.4 & 8.6 & 5.5 \\
\hline 最低速力 kt & 8.0 & 8.2 & 5.0 & 5.0 & 3.1 & 3.0 & 8.0 & 4.9 \\
\hline 最低回転数 & $\begin{array}{l}\text { 左 } 245 \\
\text { 右 } 210\end{array}$ & $\begin{array}{l}215 \\
250\end{array}$ & $\begin{array}{l}225 \\
200\end{array}$ & $\begin{array}{l}190 \\
225\end{array}$ & $\begin{array}{l}130 \\
115\end{array}$ & $\begin{array}{l}125 \\
135\end{array}$ & $\begin{array}{l}240 \\
210\end{array}$ & $\begin{array}{l}190 \\
220\end{array}$ \\
\hline
\end{tabular}

註 Advance. Transfer の項中（）内の数字は、風压を改正しないもの。 
の测定值で、別表第 2 は旋回圈測定の結果をまとめたものである。ただしデッカ位置は対 地位置であるので対水位置に換算する必要がある。

原 速面舵. $15^{\circ}$

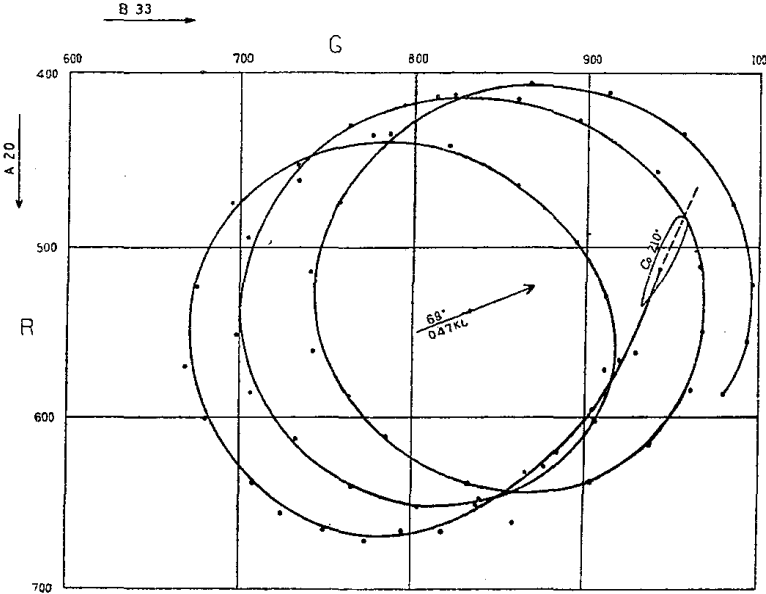

Fig. 3

（3）新針路距離の測定

新釬路距離とは船が $\theta^{\circ}$ だけ変針する 場合転舵発令の位置（A）汃ら新旧釬路 の交叉点 $(\mathrm{B})$ 亿至る旧針路上の距離 (D) をいう。(F.4 参照)

すなわち $\theta^{\circ}$ 変針する場合図上変針点

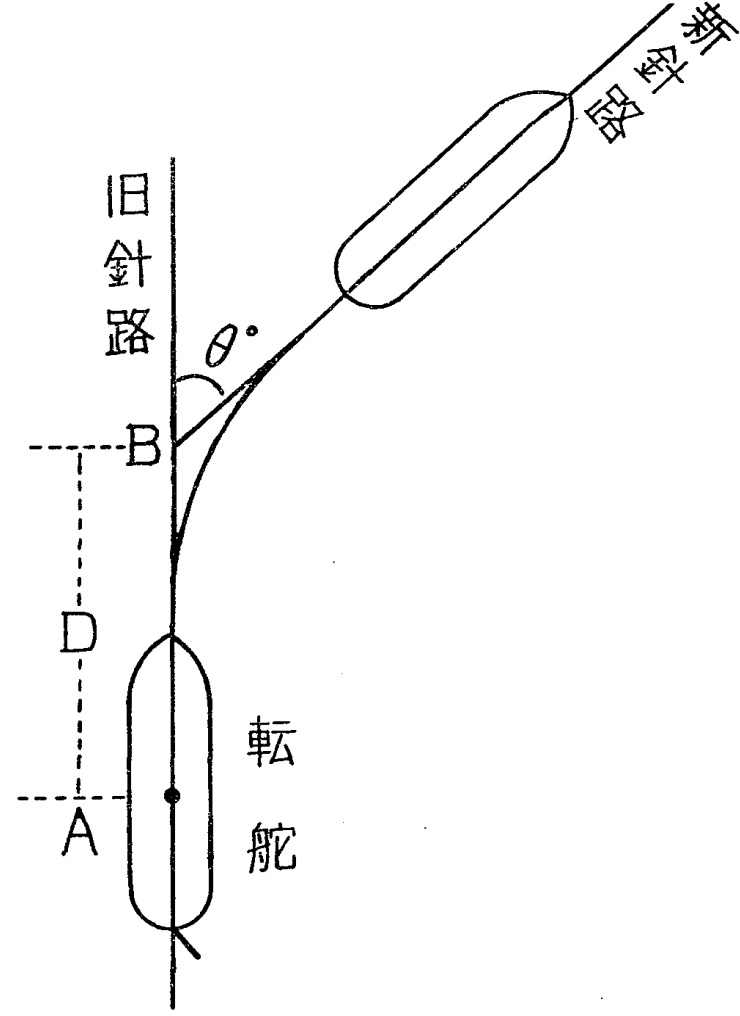

Fig. 4

Bから何 $\mathrm{m}$ 手前で転舵すれば正しく予定の新しい針路にのるかを知るととができる訳であ る。

海軍では編隊航行とか狭水道通過の場合新針路距離が極めて必要であるので非常に研究さ れており、実験式が各艦型によつてできていた。たとえば

(亻) 特型駆逐艦

速力 6〜 18kt 舵角 $20^{\circ}$ のとき $D=50 \mathrm{~m} \times \frac{\theta}{10}+50 \mathrm{~m}$

(口) 軽 巡

$$
\begin{array}{ll}
\theta=2 \mathrm{pt} \text { のき } & D=200 \mathrm{~m} \\
\theta=4 \mathrm{pt} \text { とき } & D=400 \mathrm{~m} \\
\theta=6 \mathrm{pt} \text { とき } & D=600 \mathrm{~m} \\
\theta=8 \mathrm{pt} \text { とき } & D=800 \mathrm{~m}
\end{array}
$$

となつている。

今回は僅かに 3 回しか実施しなかつたので十分な成果を得られなかつたが、機会を見て 繰返し実験して自船の新針路距離を知つておけば操船上極めて価値があると思う。成果は 紙面の都合で省略する。

\section{4. ロラン測定船位の精度}

始めて日本管理のロラン局 3 局が落石埼、大釜埼及び波埼に新設され、今年11月から業務を開 始したが、今回はその試験電波の発射期間で常時電波を出していなかつたが極力デッカ位置と比 較検討してみた。 
別表第 3. 十膯沛に括ける Loran 測定船位の精度

\begin{tabular}{|c|c|c|c|c|c|c|c|c|}
\hline \multirow{2}{*}{ 月 日 } & \multirow{2}{*}{ 時 分 } & \multicolumn{3}{|c|}{ Loran } & \multicolumn{3}{|c|}{ Decca } & \multirow{2}{*}{ 愦 $\left(\begin{array}{l}\text { Decca } \\
\text { 正しい } \\
\text { 多をする }\end{array}\right)$} \\
\hline & & $2 \mathrm{~S} 1$ & $2 \mathrm{~S} 2$ & 位置 & $\mathrm{R}$ & $\mathrm{G}$ & 位 犆 & \\
\hline \multirow[t]{2}{*}{$8 \sim 21$} & 1516 & 1871 & 3770 & $\begin{array}{r}42 \sim 42.8 \\
143 \sim 50.1\end{array}$ & C1185 & A 3459 & $\begin{array}{r}42 \sim 43.0 \\
143 \sim 50.5\end{array}$ & $\begin{array}{ll}\text { S1 } & \text { nil } \\
\text { S2 } & \text { nil }\end{array}$ \\
\hline & 1637 & 1863 & 3766 & $\begin{array}{r}42 \sim 40 \\
143 \sim 54\end{array}$ & C 0966 & A 3545 & $\begin{array}{r}42 \sim 43.0 \\
143 \sim 52.0\end{array}$ & $\begin{array}{lll}\mathrm{S} 1 & 3 \mu \mathrm{s} & 0.3 \mathrm{M} \\
\mathrm{S} 2 & 1 \mu \mathrm{S} & 2.0 \mathrm{M}\end{array}$ \\
\hline $8 \sim 23$ & 1022 & 1661 & 3759 & $\begin{array}{c}42 \sim 47 \\
144 \sim 18.5\end{array}$ & В 0213 & C 4722 & $\begin{array}{r}42 \sim 45 \\
144 \sim 23\end{array}$ & $\begin{array}{lrl}\mathrm{S} 1 & 5 \mu \mathrm{s} & 0.5 \mathrm{M} \\
\mathrm{S} 21.5 \mu \mathrm{s} & 3.0 \mathrm{M}\end{array}$ \\
\hline $8 \sim 26$ & 1530 & 1673 & 3764 & $\begin{array}{r}42 \sim 53 \\
144 \sim 10\end{array}$ & A 2225 & B 3885 & $\begin{array}{r}42 \sim 47.5 \\
144 \sim 17.0\end{array}$ & $\begin{array}{lll}\mathrm{S} 1 & \mathrm{nil} & \\
\mathrm{S} 2 & 3 \mu \mathrm{S} & 5.0 \mathrm{M}\end{array}$ \\
\hline \multirow[t]{3}{*}{$8 \sim 30$} & 1235 & 1823 & 1757 & $\begin{array}{r}42 \sim 30.5 \\
144 \sim 15.5\end{array}$ & C 1485 & B 4695 & $\begin{array}{r}42 \sim 29 \\
144 \sim 18\end{array}$ & $\begin{array}{lll}\mathrm{S} 1 & \mathrm{nil} \\
\mathrm{S} 2 & 1.5 \mu \mathrm{s} & 2.5 \mathrm{M}\end{array}$ \\
\hline & 1419 & 1935 & 3738 & $\begin{array}{r}42 \sim 09 \\
144 \sim 33\end{array}$ & D 1200 & C 4622 & $\begin{array}{r}42 \sim 08 \\
144 \sim 34\end{array}$ & 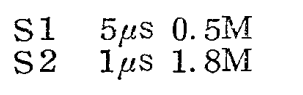 \\
\hline & 1513 & 2073 & 3720 & $\begin{array}{c}41 \sim 56 \\
144 \sim 32.3\end{array}$ & E0378 & C 4611 & $\begin{array}{r}41 \sim 53.8 \\
144 \sim 33.6\end{array}$ & $\begin{array}{lrl}\mathrm{S} 1 & 10 \mu \mathrm{S} & 1.2 \mathrm{M} \\
\mathrm{S} 2 & 3 \mu \mathrm{s} & 2.0 \mathrm{M}\end{array}$ \\
\hline $8 \sim 31$ & 1026 & 2260 & 3750 & $\begin{array}{r}41 \sim 53.7 \\
144 \sim 01.1\end{array}$ & F 0760 & B 4725 & $\begin{array}{r}41 \sim 50.4 \\
144 \sim 04.9\end{array}$ & $\begin{array}{lrl}\mathrm{S} 1 & 10 \mu \mathrm{s} & 1.0 \mathrm{M} \\
\mathrm{S} 2 & 3 \mu \mathrm{s} & 3.5 \mathrm{M}\end{array}$ \\
\hline
\end{tabular}

註 $2 \mathrm{~S} 1$ については $1 \mu \mathrm{S}$ の長さは $0.1 \mathrm{M}$ 程度で虽差 $10 \mu \mathrm{s}$ としても $1 \mathrm{M}$ 程度に過ぎない。 $2 \mathrm{~S} 2$ については丁度基線の延長上に近く $1 \mu \mathrm{S}$ の長さも $0.8 \sim 1.2 \mathrm{M} ゙$ 誤差も大きい。

その結果については别表第 3 のおりである。

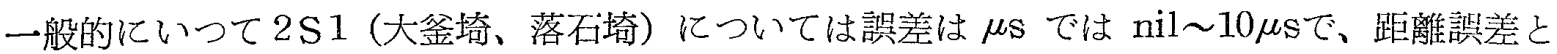
しては最大 $1 \mathrm{M}$ 程度であつた。2S2（大釜埼、波埼）については の附近の1 $\mu$ Sの長さは0.8〜1.5Mと長いため、距離俱差としては3〜5Mある場合もあつた。

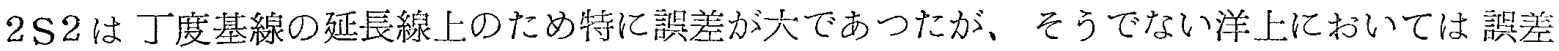
1〜2M程度（地上波の場合）には十分入るので船位測定用としてロランは極めて有效である。

\section{5. 海 流の測定}

(1) GEK（電磁式流速計）

GEKは普通の流速計と異なり、船が航行中流速を連続的に自記する流速計で、原理は「磁場 を切つて運動する導体の中には磁場と運動の双方に重直な起電力を生ずる」という「ファラディ

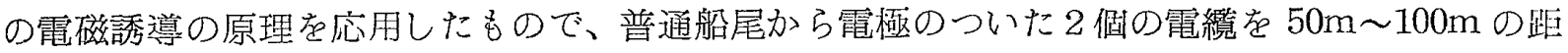
離で流し、 $m V$ 計で電圧を測定して、船首尾に直角方向の海流の分速が求められる。との場会㥲 の流速を求めるためには針路を 1 時 $90^{\circ}$ 変針する必要がある。

今船尾からの電極をそれぞれ $E_{1} 、 E_{2}$ 、電極間の距離を $l$ 、地磁気の鉛直分力を $H_{Z}$ 、針路に 直角方向の海流の分速 $(\mathrm{kt})$ を $V_{R}$ とすれば $E_{1}$ と $E_{2}$ との閻に车ずる電压 $\triangle E_{R}(m V)$ 次式で 求められる。(F.5 参照)

$$
\begin{gathered}
\triangle E_{R}=\frac{1}{20}-H_{Z} V_{R} l(m V) \\
\therefore V_{R}=\frac{20 \times \triangle E_{R}}{H_{Z} l}
\end{gathered}
$$




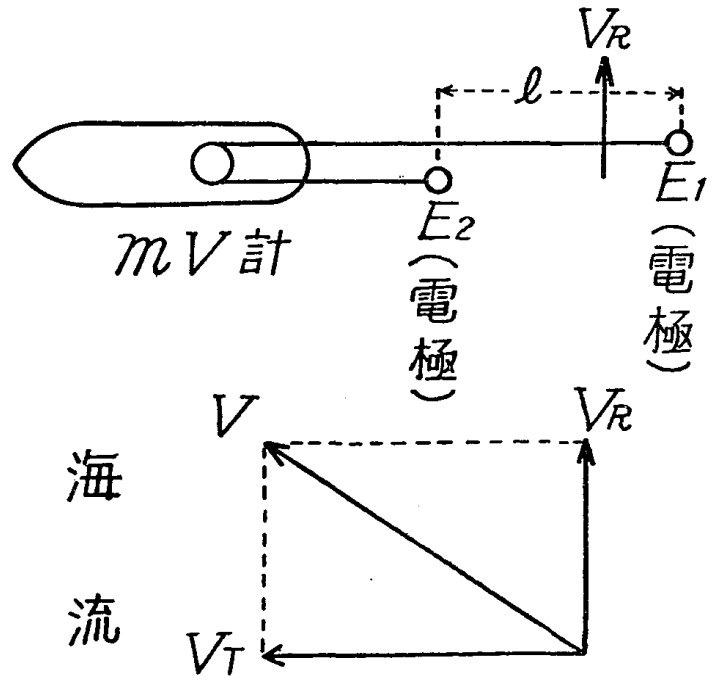

Fig. 5

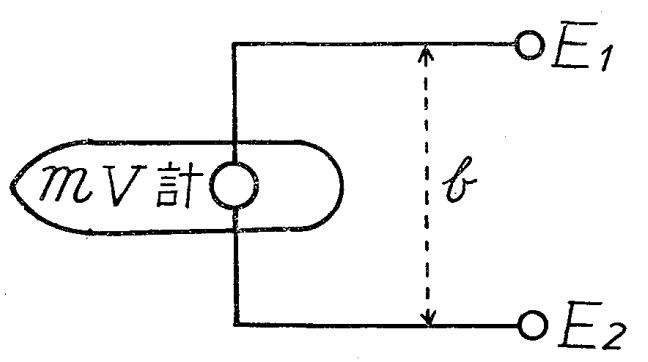

Fig. 6

この外に船側から電極を流して船首尾方向の 流速の分速を求少方法もある。(F.6 参照)

$$
\begin{aligned}
e & =\frac{1}{20} H_{Z} V_{E} b^{(m \nabla)} \\
V_{E} & =V_{S}+V_{T}
\end{aligned}
$$

但し $V_{E} \cdots \cdots$ 船速と海流の船首尾方向の分速との和

$V_{\boldsymbol{S}} \cdots \cdots$ 船の対水速度

$V_{T} \cdots \cdots$ 海流の針路方向の分速

今回は前者の方法により測定した。

(2) 実測位置（デッカ位置）と推測位置との差からら海流測定

これは一般船舶が航海中常時行なつている方法で、これによつて求めた海流とGEKによ るものとを別表第 4 亿揭載比較検討してみた。

別表第 4 .

海 流 の 測 定

\begin{tabular}{|c|c|c|c|c|c|c|c|}
\hline \multirow{2}{*}{ 月 日 } & \multirow{2}{*}{ 時 分 } & \multirow{2}{*}{ 実 測 位 置 } & \multirow{2}{*}{$\begin{array}{l}\text { GEK と } \\
\text { D.R. との別 }\end{array}$} & \multicolumn{2}{|c|}{ 海流 } & \multirow{2}{*}{\multicolumn{2}{|c|}{ 風 向 風 速 }} \\
\hline & & & & 流 向 & 流 速 & & \\
\hline \multirow{8}{*}{$8 \sim 30$} & $\begin{array}{l}11 \sim 20 \\
11 \sim 30\end{array}$ & $\begin{array}{r}42 \sim 40.0 \\
144 \sim 33.0 \\
\end{array}$ & GEK & $241^{\circ}$ & $1.2^{\mathrm{k} \hat{\imath}}$ & $\mathrm{N}$ & 2 \\
\hline & $\begin{array}{l}12 \sim 00 \\
13 \sim 00\end{array}$ & $\begin{array}{r}43 \sim 20.3 \\
144 \sim 34.0 \\
\end{array}$ & D. $\mathrm{R}$ & $230^{\circ}$ & 1.0 & " & "I \\
\hline & $\begin{array}{l}13 \sim 24 \\
13 \sim 34\end{array}$ & $\begin{array}{r}42 \sim 15.0 \\
144 \sim 34.0\end{array}$ & GEK & 276 & 1.0 & NNW & 2 \\
\hline & $\begin{array}{l}14 \sim 00 \\
15 \sim 00\end{array}$ & $\begin{array}{r}42 \sim 56.8 \\
144 \sim 33.7\end{array}$ & D. $\mathrm{R}$ & 241 & 0.9 & W & 1 \\
\hline & $\begin{array}{l}15 \sim 49 \\
15 \sim 59\end{array}$ & $\begin{array}{r}41 \sim 43.5 \\
144 \sim 31.0 \\
\end{array}$ & GEK & 279 & 1.5 & WSW & 2 \\
\hline & $\begin{array}{l}16 \sim 30 \\
17 \sim 30\end{array}$ & $\begin{array}{r}42 \sim 03.0 \\
144 \sim 29.3 \\
\end{array}$ & D. $\mathrm{R}$ & 294 & 1.0 & W & 2 \\
\hline & $\begin{array}{l}17 \sim 30 \\
18 \sim 00\end{array}$ & $\begin{array}{r}42 \sim 09.3 \\
144 \sim 30.4 \\
\end{array}$ & D. $R$ & 40 & 0.1 & WNW & 2 \\
\hline & $\begin{array}{l}18 \sim 00 \\
18 \sim 11\end{array}$ & $\begin{array}{r}42 \sim 09.0 \\
144 \sim 30.0\end{array}$ & GEK & 33 & 0.4 & "I & "I \\
\hline \multirow{4}{*}{$8 \sim 31$} & $\begin{array}{l}8 \sim 00 \\
9 \sim 00\end{array}$ & $\begin{array}{r}41 \sim 55.2 \\
144 \sim 11.8 \\
\end{array}$ & D. $\mathrm{R}$ & 253 & 0.4 & NNE & 5 \\
\hline & $\begin{array}{l}9 \sim 47 \\
9 \sim 58 \\
\end{array}$ & $\begin{array}{r}41 \sim 47.0 \\
144 \sim 08.0\end{array}$ & GEK & 284 & 0.7 & NNE & 6 \\
\hline & $\begin{array}{l}11 \sim 00 \\
12 \sim 00\end{array}$ & $\begin{array}{r}42 \sim 10.3 \\
144 \sim 12.2\end{array}$ & D. $\mathrm{R}$ & 12 & 0.3 & NNE & 4 \\
\hline & $\begin{array}{l}12 \sim 00 \\
12 \sim 10\end{array}$ & $\begin{array}{r}42 \sim 10.0 \\
144 \sim 12.5\end{array}$ & GEK & 120 & 0.3 & NNE & 5 \\
\hline
\end{tabular}

(GEK 及び 推測位置による) 
なるべく比較し易いように殆んど同時刻、同位置のもののみを取上げた。

一般に海流は弱かつたので若干違つているが、流向、流速とも大体一致しており良い絡果がで ている。

\section{6. む す び}

以上デッカの精度の良い点を利用して色々の実験を行つたが、ての外にも船の速力試験、前進 惰力、停止惰力、前進中の船首の振れ、風圧による減速等色々の測定が可能である。

たまたま今年10月国際水路局から送つてきたIHBの Review（1959年版）にオランダ海軍が デッカ航法を利用して船船の運動性能を測定した処極めて有效であつた旨の記事が記載されてい たが、今回水路部で実験したものとほぼ同じようなととを行つている。 